\title{
The Aestheticcode of Cirebon Glass Painting As Culture Capital In Arts Education
}

\author{
Casta $^{1}$, Tjetjep Rohendi Rohidi ${ }^{2}$, Triyanto ${ }^{3}$, Syakir $^{4}$, Mohammad Ibnan Syarif ${ }^{5}$ \\ \{madecasta09@gmail.com ${ }^{1}$, triyanto@mail.unnes.ac.id ${ }^{3}$ \} \\ Institut Agama Islam Bunga Bangsa Cirebon ${ }^{1}$ \\ Graduate School, Universitas Negeri Semarang ${ }^{2,3,4,5}$
}

\begin{abstract}
Glass painting as a product of culture has been inherited historically as a form of educational practice. However, the educational values are still ignored in Art Education. The objectives of this research are to reveal the aesthetic code of Cirebon glass paintings and their implications for Art Education. This research used a qualitative approach with phenomenological design. Data were collected by in-depth interviews, participant observation, and documentation studies. Data analysis was conductedthrough Interpretative Phenomenoligical Analysis. The results of the study are: 1) The aesthetic code of Cirebon glass painting is a hybrid aesthetic that prioritizes intra-esthetic and extra estheticequilibrium; and 2) The aesthetic code of glass painting is inherited, objectified, and as a social institution, it is a cultural capital that provides a direction for the approach to Art Education. The conclusion is the aesthetic code of Cirebon glass paintings prioritizes balance as a cultural capital in art education. The findings in this study are the construction of a Cultural Capital-Based Art Education Approach that will contribute to the new paradigm of Art Education.
\end{abstract}

Keywords: Aesthetic code, cultural capital, approach, art education

\section{Introduction}

Glass painting has become a cultural icon of Cirebon. This type of art also developed in Yogyakarta, and Nagasepaha-Buleleng-Bali [1] [2]. The technique of painting on glass originated in Europe (14th century), it is entered the Middle East, Japan, China, then into Indonesia and it reached the peak of its development in 1930-1950 [2] [3]. Today Indonesia's glass paintings face various problems, both those related to their sustainability, the decline in the number of painters, the sluggish market, and the proliferation of reproductions of the work of established painters.

Glass painting with all its dynamics has not been widely studied. A more reportage search in Djawa magazine about glass painting was first carried out by J.H.Hooykaas van Leeuwen Boomkam in 1939. Research by Seiichi Sasaki, WahyonoMartowikrido, and Tatsuro Hirai focused on documenting Chinese theme glass paintings with an emphasis on analyzing glass painting techniques. Jerome Samuel, the researcher from the Institut National des langues et CivilisationOrientalesdan Centre Asie du Sud-Est, Paris, emphasizes more on the historical study of the development of glass paintings in Indonesia. The study of glass painting was also carried out by Eddy HadiWaluyo (2005) as a Dissertation at Gajah Mada University with the title "Painting, Indonesian Glass Paintings, Continuity, and Change". His study emphasizes 
the inheritance process (art transmission) of glass paintings and their development in Indonesia, especially in Cirebon, Yogyakarta, Solo , and Nagasepaha-Buleleng-Bali. [2]

The four studies above further reconstruct the phenomenon of the development of glass paintings, it has notrevealed aesthetic aspects and symbolic meanings, as it is usual art, as part of the culture, in which it stores knowledge systems, system symbols, and adaptation strategy systems [4] [5]. The study of intra-esthetic and extra-esthetic aspects of glass painting, especially aspects of the aesthetic code and the symbol of acculturation in Cirebon glass paintings comprehensively to answer the problem of cultural integration in multiculture as suggested by Triyanto [6], there is also no research on the topic.

This research is conducted with a focus on a study of aesthetic codes on the cultural production of Cirebon glass paintings and their implications for art education. Therefore, the objectives of the research are 1) describe the aesthetic codes of Cirebon glass paintings; and 2) Formulate the implications of the cultural production of Cirebon glass paintings on Art Education. This study provides a scientific contribution: first, reconstructing the aesthetic code of traditional art as an Eastern aesthetic system that is very different from the Western aesthetic philosophy originating from the Greek aesthetic philosophy; and second, giving a novelty about the direction and new paradigm of Art Education which should be chosen.

\section{Methods}

This study used a qualitative approach with phenomenological design. The focus of the problem was assessed using Interdisciplinary studies. Data was collected from natural settings using interview techniques, observation, documentation, and audiovisual information. The data sources in this study were Cirebon glass paintings from the first generation, glass paintings from the community of the Tariqat (courtiers), glass paintings from the puppetry community, and glass paintings from the wider community to the last generation. Besides, to explore data that was symbolic in meaning and esthetic codes glass paintings were obtained from glass painters and humanists, as well as studies of scientific sources in the form of books or journals.

Data analysis was performed by Interpretative Phenomenological Analysis (IPA) according to Jonathan A. Smith, which focused on the process of interpreting unique personal experiences combined with interactive data analysis techniques from Miles and Huberman. The steps of analysis with IPA were carried out by conducting a dynamic application and relying on the transcripts of data that have been obtained, then carried out the analysis by steps: 1) reading and re-reading; 2) Initial noting; 3) Developing Emergent Themes; 4) Searching for connection across emergent themes; 5) Looking for patterns across case; and 6) Making Research Report.

\section{Results and Discussion}

Glass painting as a cultural expression saves aesthetic rules, symbolic meaning and storytelling [7]. At the level of aesthetic rules, Cirebon glass paintings tend to provide esthetic codes that can be traced from intra-esthetic aspects (visual elements and design principles) and extra-esthetics (ideas, themes, imagination, expressions, and styles) that interact to save symbolic meaning and cannot be separated from the cultural system. 
The aesthetic code of the Cirebon glass painting from the intra-esthetic aspect can be traced from the elements of "the description of subject matter" which can be visually observed from the characteristics of lines, colors, shapes, and management of design principles (balance, harmony, unity, contrast, and point of view). The description of the subject matter in Cirebon glass paintings generally uses the Wimba method [7] by drawing decorative objects. The choice of decorative forms (stylisation) is in line with the Islamic value system which avoids realistic idealistic visualization. Contours that limit the shape of an object or ornament are made with very firm, sharp lines and have a consistent thickness, reminiscent of Chinese paintings and confirms that glass paintings enter Indonesia from China [3]. The coloringprocessisusing opaque with a flat sweeping technique. The color composition uses polychrome from a combination of various alloys of green (godongan), purple (encungan), red-orange (TejaSumirat) compositions. The use of colors in Cirebon glass paintings consists of heraldic colors.Itsymbolizes certain meanings and colors as aesthetic (pure) expressions. The use of color is heraldically seen in glass paintings with depictions of puppet characters that obtain meaning based on the teachings of Tareqat [8] [9].

Cirebon glass paintings also have distinctive aesthetic form idioms, namely the form of Mega Mendung and Wadasan ornaments which complement the painting subject matter, whether in the form of puppet themes, landscaping, folklore, pictograph calligraphy, or calligraphy. Mega Mendung and Wadasan ornaments are influences from cloud ornaments that developed during the Ming Dynasty, China [10]. This is due to Cirebon's geocultural and geopolitical position as one of the Silk Road routes that allow cultural contact with Chinese culture and other major cultures such as Arabic, India, Java, and Europe [11], [12]. Cirebon is also one of the points of stopping Cheng Ho's expedition that brings cultural, religious and trade missions [13]. In addition, Cirebon also as the center of the spread of Islam, with its central figure, Sunan Gunung Jati who was Raja-Pandito, political leader and religious leader [14] [8], who had a wife from China, Tang Hong Tien Nio or well known asOng Tien Nio [13] [15]. This condition made the aesthetics of cloud ornaments in the treasures of Chinese culture entered, accepted, chewed, digested, and then created to new forms of culture, including the unique ornaments: Mega Mendung and Wadasan with symbolic new meanings originating from the values of Islamic teachings [16].

Mega Mendung ornaments illustrate the stylized form of clouds with a decorative pattern as a symbol of embodiment manifested by graded coloring and monochromatic color compositions. WadasanOrnamentdescribesrockstylisationas a symbol of faiththatis as strong as a coral, alsocoloredandgradedmonochromaticand has anuprightpattern. The color gradation in the Mega Mendung and Wadasan ornaments is always made odd: three, five, seven or Nine. The three-tier aesthetic is interpreted as a symbol of tri tunggal(trinity): Faith, Islam, and Ihsan. The five layers are associated with the symbol of the Pillars of Islam. The seven layers are associated with the seven processes of creating the universe as stated in the Book of Martabat Pituand the doctrine of Wahdah al Wujud [9] which is the basis for forming Cirebon culture. While the Nine-layered color gradation associated with Wali Sanga (The Nine Pious Leaders), is an attempt to refer to the position of Cirebon as the center of the spread of Islam by Wali Sanga.

Cirebon glass paintings also have aesthetic codes stored in the management of design principles, especially from the principle of balance, unity, harmony, contrast, rhythm, and point of interest. The design principles turned out to adapt to pre-Islamic values, such as the principle of the Binnary opposition, Tri Buwana, SedulurPapatKelimaPancer and Astabrata [17]. These principles stem from old values which then continue in the Islamic era in Cirebon with peaceful new meanings with values derived from Islamic teachings and form the 
characteristics of Islamic culture in Indonesia. Thus in the management of the principles of glass painting design cannot be separated from the idea or world view of the painter. The aesthetic code of Cirebon glass paintings from ideas or sources of creation ideas cannot be separated from the cultural characteristics of Cirebon which is a continuation of old preIslamic values, resulting in cultural acculturation especially from the elements of Islam, Hinduism, and China which made the expression of Cirebon culture a hybrid [ 18].

The Binary Opposition aesthetic in Cirebon glass painting is realized by juxtaposing the balance constructed with the dominant main object as the content (existence) combined with the background of the empty painting (absence). This paradox then presents a more transcendental dimension and the difference is the basis of strength to obtain balance and unity. The Tri-Buwana aesthetic is seen in the way of the wimba which divides the field of glass painting into three parts: the lower part (the weakness which usually consists of a series of Wadasan and Pandanan ornaments), the middle part (subject matter as the main character, and the upper part (duwuran filled with Mega Mendhung ornament series). The aesthetic construction of Tri-Buwanahas the meaning of Tasawuf teachings, namely the teachings of ManunggalingKawulaGusti with the method of taraqi (ascent) and Tanajul (Decline) and the middle world is metacosmos which acts as a counterweight to unity. [9] [17] The conception of the Tri-Buwana rule is very clear in the KerataPaksi Naga Liman object.

The aesthetics of SedulurPapatKelimaPancerin Cirebon glass paintings uses the principle of centered balanceand forms a unity with the main elements as the center and the four elements found in each corner. This concept is interpreted as a manifestation of the potential of lust that is naturally owned by humans, they are Lawwamah (North) lust, Supiah (West) lust, amarah (South) lust, and muthmainah (East) lust, with Pancer (Center), is Jauhar awwal (first light ) This concept is also found in Cirebon Mask art [19].

Therefore, the aesthetic code of Cirebon glass paintings is hybrid, mixing, and sustaining the values and aesthetic codes of the pre-Islamic era, Chinese culture, Islamic culture, and Javanese culture, but later, it becomes a unique cultural entity. Puppet themes, pictograph calligraphy (Srabad, Banteng Windu, Macan Ali, Majnun Allah, Sayidina Ali, Hiro Cave, and Buroq), the landscape of mosques, trains and other decorative objects, present with unique and unique aesthetics, displaying multicultural acculturation. The aesthetic code of Cirebon glass paintings prioritizes the balance between intra-esthetics and extra-esthetics. There is no intraesthetics that ignores the extra-esthetic aspects and vice versa.

The aesthetic code in Cirebon glass paintings is inherited historically, from one generation to the next generation . in Bourdieu's perspective, it is classified as Habitus [20], as the disposer of actions to the glass painters. The aesthetic code is objectified in the form of artwork and can be used as a social institution. Therefore, the aesthetic code of Cirebon glass paintings with the three entities above is identical to cultural capital in Bourdieu's perspective. The aesthetic codes as cultural capital have been fostered in the family environment and can be reproduced in the school environment, which can be exchanged with economic capital, social capital, and symbolic capital [21]. According to Bourdieu, cultural capital is in the form of knowledge, skills, education, and benefits that a person or group has that gives status in society. In this case, cultural capital can be realized through inheritance, objectified, and institutionalized [22] [21].

Referring to the substance of the aesthetic code of glass paintings as cultural capital and its dimensions in Bourdieu's perspective, then school through art education has an important role in reproducing cultural capital. Therefore, it is expected that Art Education in schools can be in line with the UNESCO Art Education Roadmap, namely developing cultural awareness and foster student creativity [23] and foster character education [24], the implication is the 
need for a new approach to art education, namely the Educational Approach Cultural Capitalbased Art. This new approach reinforces the role of Art Education as a medium for reproducing cultural capital: 1) efforts to foster and foster student familiarity with a legitimate culture; 2) Cultural literacy; 3) Involvement in artistic creativity activities, and 4) cultural communication. This concept is in line with the concept of cultural capital in Bourdieu's perspective, therefore, the Culture-Based Art Education Approach adheres to a legitimate model of inheriting cultural systems with its local wisdom as its substance [4], providing spaces for adequate understanding of cultural literacy, providing cultural experiences through cultural activities, and providing the possibility of cultural communication through art education. Consider the picture of the conceptual scheme of the Cultural Capital-Based Art Education Approach below.

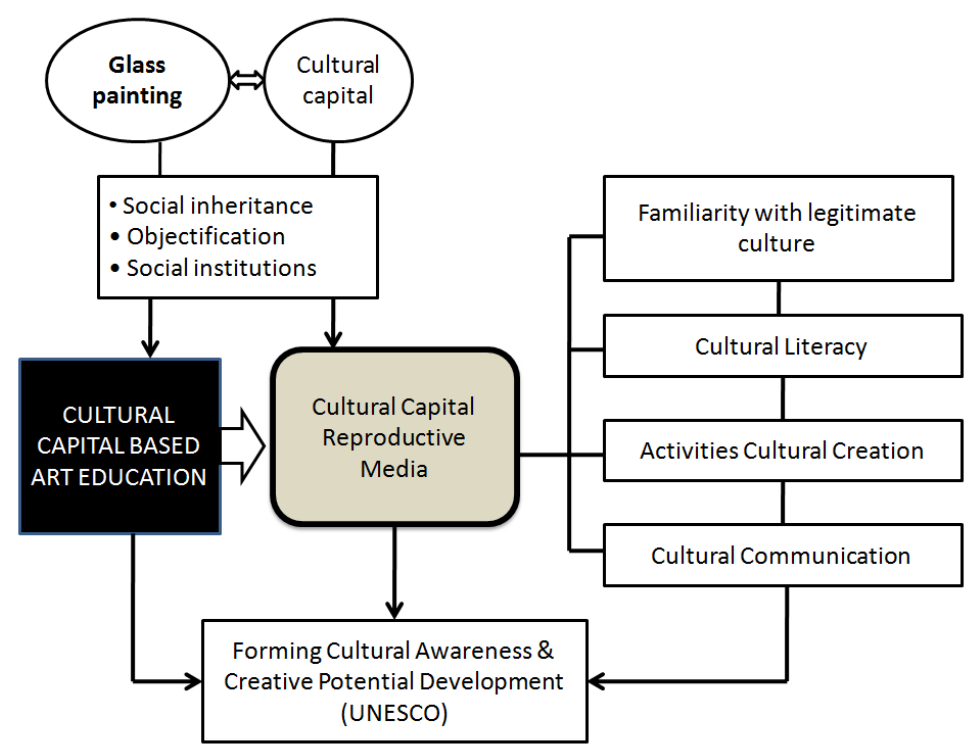

Fig. 1. Model of Cultural Capital-Based Art Education Approach

\section{Conclusion}

Cirebon glass paintings as cultural products have a hybrid aesthetic code, it becomes independent, unique and carries the realization of intra-esthetic balance (visualization) and extra-esthetic (value of symbolic meaning), a balance between "beautiful inside" and "beautiful outside". The aesthetic code of Cirebon glass paintings is inherited historically, objectified, and as a social institution which in Bourdieu's perspective is cultural capital that can be fostered in the family and school environment. Therefore, it is expected that art education can foster students' cultural awareness and creativity. Morever a new approach is needed in the formal education curriculum, it is the Cultural Capital-Based Art Education Approach. 


\section{References}

[1] Eddy Hadi Waluyo, Lukisan Kaca Cirebon dari Masa Awal Hingga kini, 1st ed. Bandung: P4ST UPI, 2006.

[2] Samuel Jerome, "Naissances et renaissance de la peinture sous verre à Java," Archipel, vol. 69, pp. 87-126, 2005.

[3] Samuel Jerome, "À la recherche des ateliers perdus. Peinture sous verre et production en série à Java 1," Archipel, vol. 94, pp. 143-169, 2014.

[4] Triyanto, "Art Education Based on Local Wisdom," in Proceeding of International Conference on Art, Language, and Culture, 2017, vol. 2, no. 1, pp. 33-39.

[5] T. . Rohidi, "Ekspresi Seni Orang Miskin," J. Budaya Nusant., vol. 2 No. 1, pp. $7-$ 8,2015

[6] M. Triyanto, Nur Rokhmat, "Warak Ngendog: Simbol Akulturasi Budaya pada Karya Seni Rupa,” J. Komunitas, vol. 5, no. 2, pp. 267-279, 2013.

[7] P. Tabrani, "Prinsip-Prinsip Bahasa Rupa," Budaya Nusant., vol. 1, no. 2, pp. $183-$ 195, 2018.

[8] A. Yani, "Pengaruh Islam Terhadap Makna Simbolik Budaya Keraton-Keraton Cirebon," Holistik, vol. 12, p. 16, 2011.

[9] M. EL-Mawa, "Naskah Syattariyyah Cirebon: Riset Awal dalam Konteks Jejaring Islam Nusantara," in Annual Conference on Islamic Studies, 2010, no. November, pp. 309-322.

[10] M. T. Riyanti, M. Rouselyn, and W. Jakarta, "the Influence of Art Motif Batik Mega Mendung Cirebon to Fesyen in Jakarta," Rouselyn, vol. 6, no. 3, pp. 105$125,2018$.

[11] M. A. Humaedi, "Budaya Hibrida Masyarakat Cirebon," HUmaniora, vol. 25, no. 3, pp. 281-295, 2013.

[12] A. Jaelani, "Cirebon as the Silk Road: A New Approach of Heritage Tourisme and Creative Economy," J. Econ. Polit. Econ., vol. 3, no. June 2016, pp. 415-428, 2016.

[13] D. Rosmalia and L. E. Prasetya, "Development of cultural tourism area based on the spiritual space of Cirebon Keraton," IOP Conf. Ser. Earth Environ. Sci., vol. 126, no. 1, pp. 0-10, 2018.

[14] D. Hamdani, "Cultural System of Cirebonese People: Tradition of Maulidan in the Kanoman Kraton Sistem Budaya Masyarakat Cirebon: Tradisi Maulidan dalam Kraton Kanoman," vol. 4, no. 95.

[15] S. Al Qurtuby, "The Tao of Islam: Cheng Ho and The Legacy of Chinese Muslims in Pre-Modern Java," Stud. Islam. Indones. J. Islam. Stud., vol. 16, no. 1, pp. 5178, 2009.

[16] dkk Agus Salim, "Dekonstruksi Motif Batik Keraton Cirebon: Pengaruh Ragam Hias Keraton pada Motif Batik Cirebon oleh Agus Nursalim Harry Sulastianto Zakiah Pawitan Departemen Pendidikan Seni Rupa-FPSD Universitas Pendidikan Indonesia ABSTRAK Motif batik Keraton Cirebon me," Ritme, vol. 2, no. 1, pp. 58-69, 2016.

[17] Dharsono, "Estetika Nusantara Orientasi terhadap Filsafat, Kebudayaan, Pandangan Masyarakat, dan Paradigma Seni," in Seminar Nasional Estetika Nusantara ISI Surakarta, 2010, pp. 4-35.

[18] M. A. Humaedi, "Budaya Hibrida Masyarakat Cirebon," vol. 25, no. 3, 2013.

[19] D. N. Hamidah, "Pengaruh tarekat pada topeng cirebon," Holistik, vol. 12, no. 2, 
pp. 41-59, 2011.

[20] T. Bennett, "Habitus Clivé: Aesthetics and Politics in the Work of Pierre Bourdieu," New Lit. Hist., vol. 38, no. 1, pp. 201-228, 2007.

[21] I. G. Andersen and M. M. Jæger, "Cultural capital in context: Heterogeneous returns to cultural capital across schooling environments," Soc. Sci. Res., vol. 50, pp. $177-188,2015$.

[22] C. B. M. Kamphuis, T. Jansen, J. P. Mackenbach, and F. J. Van Lenthe, "Bourdieu's cultural capital in relation to food choices: A systematic review of cultural capital indicators and an empirical proof of concept," PLoS One, vol. 10, no. 8,2015 .

[23] E. Sugiarto, "Nilai-Nilai Karakter Dalam Pembelajaran,” Sadbda, vol. 8, pp. 52-62, 2013.

[24] S. Salam, "Potensi Unik Pendidikan Seni dalam Pengembangan Karakter," Semin. Nas. Dies Natalis UNM Ke 57, 9 Juli 2018, pp. 21-34, 2018. 